Moderados, Exaltados and Caramurus in the Rio de Janeiro press: the struggles and the representations of Evaristo Ferreira da Veiga (1831-1835)

\title{
Moderados, Exaltados e Caramurus no prelo carioca: os embates e as representações de Evaristo Ferreira da Veiga (1831-1835)
}

Marcos Ferreira de Andrade

Doutor em História pela Universidade Federal Fluminense (UFF-Niterói/Brasil) e professor no Departamento de História da Universidade Federal de São João del-Rei (UFSJ-São João Del Rei/ Minas Gerais)

e-mail: marcos.andrade@pq.cnpq.br

Janaína de Carvalho Silva

Mestranda em História pela Universidade Federal de São João del Rei (UFSJ-São João Del Rei/ Minas Gerais) e-mail: jcarvalho@gmail.com

\section{Resumo}

0 presente artigo tem por objetivo analisar os embates entre os distintos grupos políticos regenciais e as representações feitas de Evaristo Ferreira da Veiga em alguns dos jornais que circularam no Rio de Janeiro e que buscaram abalar a hegemonia então usufruida pela facção liberal moderada a que ele pertencia. No período analisado, entre 1831 e 1835, os moderados ocuparam a maior parte dos cargos de poder, mas nem por isso deixaram de ser atacados, tanto pelos adversários exaltados e caramurus, quanto por indivíduos que se diziam pertencentes ao mesmo grupo, embora não concordassem com todos os seus atos.

\section{Abstract}

This article analyzes the struggles between different political groups of the Regency period and the representations of Evaristo Ferreira da Veiga in some of the newspapers published in Rio de Janeiro that sought to challenge the hegemonic position maintained by the moderate liberal wing to which he belonged. During the period under analysis, the moderados occupied the majority of power positions, something that did not put them apart from the attacks both from their exaltados and caramurus rivals, and from individuals claiming to belong to the same group despite not agreeing with all their acts.

Palavras-chave

imprensa, embates políticos, representações, Evaristo Ferreira da Veiga

Keywords

press, political struggles, representations, Evaristo Ferreira da Veiga 
1

0 trabalho é resultado de um projeto de pesquisa mais amplo que teve por objetivo analisar a trajetória politica de Evaristo Ferreira da Veiga, desde 1827 até 1837, e contou com o apoio e financiamento do CNPq e da FAPEMIG.

2

Os originais pertencem ao acervo da Biblioteca Nacional do Rio de Janeiro e foram consultados a partir dos microfilmes adquiridos da referida instituição, que, posteriormente, foram digitalizados para facilitar a montagem do banco de dados de informações dos periódicos que fizeram parte do projeto de pesquisa.

SOUZA, Otávio Tarquínio de. História dos fundadores do Império do Brasil. Rio de Janeiro: José Olympio Editora, 1972, vol.5. p.274-281.

ANDRADE, Marcos Ferreira de. Família e politica nas Regências: possibilidades interpretativas das cartas pessoais de Evaristo da Veiga (1836-1837) In: RIBEIRO, Glady Sabina; FERREIRA, Tânia Maria Tavares Bessone da Cruz (orgs.). Linguagens e práticas da cidadania no século XIX. São Paulo: Alameda, 2010. p.254

VALLADÃO, Alfredo. Campanha da Princeza (1821 -1909). Rio de Janeiro: Leuzinger S.A. 1940. p.123.
0 trabalho em questão abordará os embates entre as distintas faç̧ões políticas dos anos iniciais do período das Regências e as representações feitas pelos opositores de Evaristo Ferreira da Veiga, elaboradas através da imprensa periódica da época, não somente com o intuiuto de desacreditar o homem político que ele era, mas de convencer a sociedade acerca da necessidade de acabar com o domínio exercido pelo grupo moderado no qual ele se inseria. Por outro lado, não deixaremos de analisar a contrapartida dessa história, ou seja, a percepção que Evaristo transmitia do quadro político de então e como defendia a atuação de sua facção, e por conseguinte, a si mesmo.'

Entre os impressos de orientação liberal exaltada consultados, constam os seguintes: A Matraca dos Farroupilhas, 0 Clarim da Liberdade, 0 Exaltado, 0 Jurujuba dos Farroupilhas, 0 Evaristo e O Sentinella da liberdade no Rio de Janeiro; de orientação caramuru: O Carijó, O Caramuru, O Verdadeiro Caramuru e D. Pedro I. Por fim, também analisamos os periódicos: 0 Sete d'Abril - o qual se dizia moderado, mas fazia várias críticas a Evaristo e a outros membros do seu grupo político -, e o Aurora Fluminense, no qual Veiga defendia veementemente a moderação. ${ }^{2}$ Contudo, essas divisões de orientação política acabaram sendo inconsistentes, como veremos.

\section{0 moderado Evaristo Ferreira da Veiga}

De acordo com Otávio Tarquínio de Souza, Evaristo Ferreira da Veiga nasceu em 1799 e era filho do português Francisco Luiz Saturnino Veiga e da brasileira Francisca Xavier de Barros. Seu pai viera para o Brasil em 1784 e depois de ter servido na milícia da paróquia de Santa Rita, no Rio de Janeiro, exerceu carreira no magistério durante dezesseis anos. Evaristo o tivera como único professor até a idade de doze anos, sendo iniciado numa educação mais propriamente literária, com ênfase no Latim, Francês, Inglês, Retórica, Poética, Filosofia racional e moral. Depois aprofundara esses estudos, frequentando aulas de outros professores, algumas no Seminário de São José. Contudo, não conseguira concretizar seu projeto de estudar em Coimbra e compensara a falta de um curso universitário explorando as obras da livraria que seu pai montara após abandonar a função de mestre-escola. ${ }^{3}$ Ou seja, o futuro deputado e redator da Aurora Fluminense tivera uma formação, em grande parte, autodidata.

A partir de 1818, a família Veiga, composta do pai Francisco Luiz Saturnino da Veiga, da mãe Francisca Xavier de Barros e de quatro filhos, João Pedro da Veiga, Evaristo Ferreira da Veiga, Bernardo Jacinto da Veiga e Lourenço Xavier da Veiga, separou-se. Nesse mesmo ano Bernardo fixara-se em Campanha da Princesa, no sul de Minas Gerais, sendo acompanhado, em 1822, por Lourenço. Os dois irmãos buscavam o tratamento de males estomacais e do fígado, através do consumo das águas minerais de Águas Virtuosas da Campanha, atual cidade de Lambari e, na época, parte do termo de Campanha. Instalaram-se na sede do termo, certamente por ser mais urbanizada e oferecer melhores condições de hospedagem. ${ }^{4}$ De acordo com Alfredo Valladão, os Veigas da Campanha refletiriam na imprensa, na loja de livros e na ação patriótica, os Veigas que ficaram no Rio de Janeiro. Tudo na mais íntima comunhão com os mesmos. ${ }^{5}$ Os irmãos de Evaristo logo adquiriram uma destacada importância na política local e provincial e representaram tanto um capital político de grande relevância para a construção da hegemonia liberal moderada na região, no período das Regências, quanto para as três legislaturas de Evaristo ao Parlamento Nacional 
6

ANDRADE, Marcos Ferreira de. Familia e política nas Regências..., Op. Cit.

VEIGA, Miranda. O Panfletário da Regência, p.16. Apud. SOUZA, Otávio Tarquínio. Op. Cit. p.299-300.

8 Ibidem, p.300-309.

9

MOREL, Marco. As transformações dos espaços públicos: imprensa, atores políticos e sociabilidades na cidade Imperial (1820-1840). São Paulo: HUCITEC, 2005. p.184.

10

ANDRADE, Marcos Ferreira de. Elites regionais e a formação do Estado imperial brasileiro: Minas Gerais - Campanha da Princesa (1799-1850). Rio de Janeiro: Arquivo Nacional, 2008. p.233.

11

BASILE, Marcello Otávio Neri de Campos. 0 Império em construção: projetos de Brasil e a ação política na Corte Regencial. Tese (Doutorado em História Social). Instituto de Filosofia e Ciências Sociais, Universidade Federal do Rio de Janeiro, Rio de Janeiro, 2004. p.25

12

Ibidem
$(1830,1834,1838)$, representando sempre a província de Minas Gerais e na última também a do Rio de Janeiro. ${ }^{6}$

0 comércio de livros foi uma das especialidades da família Veiga. Ainda na mocidade de Evaristo, seu pai, Francisco Luiz, estabelecera uma livraria na Rua da Alfândega, no Rio de Janeiro. Com a morte de D. Francisca em 1823, Evaristo e João Pedro, os irmãos que ficaram no Rio, abriram outra livraria em sociedade, localizada na esquina das Ruas da Quitanda e São Pedro. Para abrirem a loja, os irmãos utilizaram-se da parte que Ihes coube da herança materna, liberada pelo pai antes de contrair novo casamento, com o intuito de "evitar quedas que a corrupção frequentemente oferece."7 0 negócio dos livros era muito lucrativo e, já em 1827, Evaristo pôde separar-se do irmão, comprando a livraria do francês João Batista Bompard. Assim, João Pedro continuara com a loja da Rua da Quintada, esquina da Rua de São Pedro, e Evaristo fora para a Rua dos Pescadores, no 49, em cujo sobrado estabeleceu também a sua residência. A loja de Evaristo, nessa época, venderia obras de Economia Política, Administração, Finanças, Say, Ricardo, Ganilh, Sismonde, livros sobre os Estados Unidos e México, Broussais, Magendie, Voltaire e uma tradução de Racine feita por Cândido Lusitano. Muitas das ideias presentes nessas obras foram divulgadas em seu jornal. ${ }^{8}$

Analisando as origens de Evaristo Ferreira da Veiga constata-se que ele não pertencia a uma familia com grandes posses ou que possuisse títulos nobiliárquicos no século anterior, embora também não se possa dizer que fosse pobre. Marco Morel, ao esboçar o perfil coletivo dos formadores de opinião do período, constatou que se a origem familiar imbricava na ascensão política, o uso público da palavra também possibilitava a integração ao poder. ${ }^{9}$ Evaristo estava nesse último caso e passara a exercer papel determinante na esfera pública com a redação da Aurora Fluminense. Em Minas Gerais, seus irmãos iniciariam a redação da Opinião Campanhense em 1832 e assim, a atividade jornalística e política transformou-se em outra especialidade da família Veiga, a qual vai ter continuidade com os seus descendentes..$^{10}$ Podemos então dizer que o prestígio do sobrenome Veiga iniciara-se com a geração de Evaristo e seus irmãos.

0 periódico Aurora Fluminense foi fundado por José Apollinário de Moraes, José Francisco Sigaud e Francisco Chrispiniano Valdetaro. De início, Evaristo era apenas um colaborador, mas logo passaria a redator principal e, a partir de 1829, o único redator da folha que the abriria as portas para a carreira política. 0 jornal esteve ininterruptamente em circulação entre 21 de dezembro de 1827 e 30 de dezembro de 1835, em um total de mil cento e trinta e seis números regulares e duzentas e setenta e seis páginas. Após esse período, entre maio de 1838 e julho de 1839, circulou na Corte outra folha com o mesmo título, mas que nada tinha a ver com a anterior, uma vez que Evaristo da Veiga morrera em 1837 e seu grupo, liberal moderado, não mais existia." $\mathrm{A}$ Aurora circulava três vezes por semana e geralmente continha quatro páginas por exemplar, contudo esporadicamente apresentava-se com seis ou até mesmo oito páginas.

A estabilidade da folha era incomum para a época em que circulava. A assinatura trimestral custava, a princípio, dois mil réis, passando para 0 dobro em 1834. 0 preço de cada exemplar não era informado, mas segundo Marcello Basile, a julgar pelo valor da assinatura, devia custar, como outros de sua espécie, em torno de sessenta réis. ${ }^{12}$ Durante toda a sua existência, utilizou como epígrafe a quadra produzida por D. Pedro I: "Pelo Brasil dar a 
MOREIRA, Luciano da Silva. Imprensa e política: espaço público e cultura política na província de Minas Gerais (1828-1842). Dissertação (Mestrado). Faculdade de Filosofia e Ciências Humanas. Universidade Federal de Minas Gerais, Belo Horizonte, 2006. p.118.

14

BASILE, Marcello. O Império em construção..., Op Cit., p.24.

15

Sobre o posicionamento da Aurora Fluminense no Primeiro Reinado e a leitura que fazia das facções políticas atuantes, ver o estudo inédito de CARVALHO, Janaina Silva. A Aurora Fluminense e o combate ao despotismo (1827-1831). Monografia (graduação em História). Universidade Federal de São João Del-Rei, São João Del-Rei, 2010.

16

0 artigo 174 da Constituição de 1824 já estabelecia a possibilidade de reforma de alguns de seus artigos, depois de cumprido o prazo de quatro anos, caso houvesse proposição por escrito da Câmara dos Deputados, com aprovação de no mínimo um terço de seus membros. Ver: Constituição Política do Império do Brazil (de 25 de Março de 1824). Disponivel em: http:// www.planalto.gov.br/ccivil_03/constituicao/ constitui\%C3\%A7ao24.htm. Acessado em 20/03/2012. Por conseguinte, desde 1828 já começariam a surgir as primeiras reivindicações de reformas, as quais seriam prontamente rechaçadas pelo governo de $D$. Pedro I. $E_{1}$ já nos momentos finais do reinado desse monarca, durante a sua viagem a Minas, fizera uma proclamação aos cidadãos de Ouro Preto, para que o ajudassem no combate à facção que atentava contra a Constituição. A partir daquele momento, os moderados, que em geral não eram muito convencidos da necessidade das reformas das leis, passaram a apoiar em parte aos exaltados que militavam naquele sentido. E juntos, os dois grupos lograriam provocar a abdicação do Imperador. Entretanto, a união seria momentânea e, no contexto regencial, os moderados dominariam os postos de decisão. $\mathrm{E}$ ainda que fossem constantemente pressionados pelos exaltados e pela opinião pública, seriam eles que dariam a direção às reformas. Assim, no final das sessões legislativas de 1831, a Câmara dos Deputados, de maioria moderada, enviaria ao Senado um primeiro projeto de reformas, da autoria de Miranda Ribeiro, o qual somente seria devolvido bem próximo ao final da legislatura do ano seguinte. As emendas dos senadores suprimiram ou modificaram vários dos artigos do projeto e propuseram reformas em outros artigos constitucionais, as quais beneficiariam unicamente à sua Câmara. Diante da protelação do Senado, os moderados tentariam um golpe de Estado, no sentido de converter a Câmara dos Deputados em Assembléia Constituinte e fazer adotar a chamada Constituição de Pouso Alegre, que contemplava as principais reformas pretendidas. Entretanto, parte dos moderados não aderiu ao golpe e frustrou-se a iniciativa. Então a Câmara dos deputados conformar-se-ia com as reformas estipuladas na Lei de outubro de 1832 , muito mais parecida com as emendas
vida/Manter a Constituição/ Sustentar a Independência/ É a nossa obrigação". De acordo com Luciano Moreira, na imprensa periódica as epígrafes eram utilizadas como uma carta de apresentação dos redatores, mostrando os propósitos que os norteavam. ${ }^{13}$ Marcello Basile sugere que a utilização da epígrafe acima era irônica, ${ }^{14}$ pelo fato de ser composta por versos da autoria de D. Pedro I. De fato, a Aurora faria intensa oposição aos ministérios instituídos por esse monarca no Primeiro Reinado e relembrá-lo-ia de forma negativa durante as Regências. Contudo, independente da origem da epígrafe, aqueles eram os propósitos da Aurora Fluminense, sustentar a independência e manter a Constituição. A oposição que fizera anteriormente ao primeiro Imperador brasileiro, em parte advinha da suspeita de seu envolvimento e maior afeição por um grupo considerado recolonizador, atuante naquele contexto. ${ }^{15} \mathrm{E}$, quanto à Constituição, mesmo aceitando que fosse reformada durante o período regencial, ${ }_{1}^{16}$ defendia que fosse conforme o estabelecido nela própria.

Assim, em 1831, Evaristo transcreveu um artigo do periódico Olindense, concordando com o mesmo, do qual ressaltamos o seguinte trecho: "Se a Constituição precisa de algumas reformas como supomos, venham elas pela via legal, pelo modo que ela mesma prescreve nos artigos $175^{17}$ e seguintes, e não se lembrem os Srs. Deputados de arrogar a si direitos que não tem." 18

De acordo com Marcello Basile, as informações sobre as tiragens dos periódicos são precárias, o que impede o pesquisador de fazer uma estimativa precisa acerca do alcance da imprensa e de seu público leitor. Entretanto, no caso da Aurora Fluminense, aponta a informação trazida no próprio periódico, acerca do número de seus subscritores, em 1831. ${ }^{19}$ Comentaremos 0 artigo indicado pelo autor integralmente, porque pretendemos utilizá-lo para ilustrar outra consideração que queremos fazer.

No artigo, Evaristo respondia ao comentário que o Sr. Hollanda Cavalcante fizera em seu periódico, Tempo, de que a única outra folha que lia com prazer era a Nova Luz. Evaristo então apontou que algum moralista impertinente poderia censurar o Sr. Cavalcante por gostar de calúnias, grosserias e obscenidades. Porém, colocava que "a plena liberdade e mesmo licença que deve haver a respeito dos gostos", o justificaria de todo. E era exatamente no "gosto" que estaria, de acordo com Evaristo, a diferença entre Cavalcante e os leitores da sua Aurora. Assim se referiu aos seus 1100 subscritores, que pareciam gostar de uma "linguagem acanhada, tímida e de doutrinas de prudente moderação", ao contrário do seu antagonista. ${ }^{20}$

De fato, podemos tirar desse artigo duas considerações: a primeira já fora apontada por Marcello Basile ao afirmar que o número de subscritores assinalado era bastante expressivo para a época. Isso em relação à população diminuta da Corte, cerca de duzentos mil habitantes, o índice elevado de analfabetismo, a concorrência de dezenas de outros jornais e o fato da Aurora ser um periódico exclusivamente político e com uma linha partidária bem demarcada, voltado, portanto, para um público mais específico. 0 autor ressalva ainda o fato de o número de subscritores não englobar o montante das pessoas que compravam a folha avulsamente nas lojas, o que de certo aumentaria em muito a quantidade de leitores do jornal. ${ }^{21}$ Sem contar aqueles que o liam de outra forma, por meio de empréstimos e da leitura coletiva. Conforme aponta Morel, a leitura, como nos tempos do Antigo Regime, não se limitava a um ato individual e privado, mas ostentava contornos coletivos. Nesse sentido, a circulação do debate político ultrapassava o público leitor visado pelos impressos. ${ }^{22} \mathrm{~A}$ segunda consi- 
dos senadores do que com o projeto inicial. Ver: GUIMARÃES, Lucia Paschoal. Liberalismo moderado: Postulados ideológicos e práticas políticas no Periodo Regencial (1831-1837). In:_ ; PRADO, Maria Emília (orgs.). 0 liberalismo no Brasil Imperial: origens, conceitos e prática. Rio de Janeiro: Revan: UFRJ, 2001. p.118-121; FILHO, Arnaldo Fazoli. O Período Regencial. São Paulo: Ática, 1990.

17

0 artigo 175 estabelecia a forma em que deveriam ser apresentadas as proposições de reforma à Câmara dos Deputados. 0 artigo 176 versava sobre a expedição e sanção da Lei de Reformas confeccionada pelo Legislativo, a qual depois de promulgada deveria ser ainda apresentada aos eleitores dos deputados da seguinte legislatura para que Ihes conferissem a faculdade de fazer tais alterações. 0 artigo 177 estipulava a maneira em que se faria propriamente a mudança ou adição à Constituição, depois de passar por todo o processo de discussões e deliberações legislativas. Por fim, 0 artigo 178 prescrevia a natureza dos artigos que eram constitucionais e que precisavam passar por todo o trâmite anterior para serem reformados. Os demais artigos da Constituição poderiam sofrer alteração ordinariamente, sem aquelas formalidades. Ver: Constituição Política do Império do Brazil (de 25 de Março de 1824). Disponivel em: http://www.planalto. gov.br/ccivil_03/constituicao/constitui\%C3\%A7a024. htm. Acessado em 20/03/2012.

18

Aurora Fluminense, n.524, 29/08/1831, p.2222-2223. Todas as citações extraídas dos periódicos e utilizadas neste artigo foram ortograficamente atualizadas.

19

BASILE, Marcello. O Império em construção..., Op Cit., p.25.

20

Aurora Fluminense, n.537, 30/09/1831, p.2279.

21

BASILE, Marcello. O Império em construção..., $0 p$. Cit., p.25.

22

MOREL, Marco. Os primeiros passos da palavra impressa. In: MARTINS, Ana Luiza; LUCA, Tania Regina de (orgs.). História da imprensa no Brasil. São Paulo: Contexto, 2008. p.39.

23

LUSTOSA, Isabel. Insultos impressos: A guerra dos jornalistas na Independência (1821-1823). São Paulo: Companhia das Letras, 2000.

24

CARVALHO, José Murilo de. História intelectual no Brasil: a retórica como chave de leitura. Topoi, Rio de Janeiro, n.1, p.139-141. Disponivel em: http://www.ifcs.ufrj.br/ ppghis/pdf/topoi1a3.pdf Acessado em: 20/03/2012.

25

Ver: BASILE, Marcello. 0 Império em construção..., Op. Cit., p.136. 0 autor faz um pequeno levantamento bibliográfico da maioria dos redatores de impressos aqui consultados.

Aurora Fluminense, n.722, 16/01/1833, p.3086. deração diz respeito à linguagem do jornal. Evaristo criticava os outros jornais de seu tempo por se utilizarem de insultos pessoais. Assim, exaltava o seu próprio jornal, que ao contrário, era prudente, acanhado e não caIunioso, adequado, portanto à sua linha política moderada. De fato, Isabel Lustosa chamou a atenção para essa peculiaridade herdada da nascente imprensa brasileira, a qual Evaristo criticava. A autora a identifica como o laboratório em que tiveram lugar embrionárias e imprevisíveis formas de competição política, que, na maioria dos casos, abria mão de insultos ao se referir aos adversários. ${ }^{23}$

Entretanto, Evaristo não deixaria de responder às provocações de seus adversários, muitas vezes utilizando-se dos mesmos recursos que censurara. De acordo com José Murilo de Carvalho, quase todos os panfletos e jornais do início do século XIX prometiam, de início, adotar uma linguagem e posição equilibrada. Mas a promessa era quase sempre quebrada. 0 autor tenta explicar o fenômeno pela ótica da retórica. Entre as suas regras, aponta para aquela que exige do orador virtude, competência e honestidade. A exigência era adequada para os jornalistas, uma vez que quase todos eram políticos. Por outro lado, o chamado argumentum ad personam envolvia a desqualificação do adversário. Assim, José Murilo de Carvalho demonstra como o estilo dos jornalistas, sendo todos versados em Retórica, era condizente com os princípios da dita disciplina. ${ }^{24}$

Como exemplo de uma provocação feita por Evaristo, podemos citar a passagem abaixo, que foi dirigida ao redator do Exaltado, o padre Marcelino Pinto Ribeiro Duarte, ${ }_{1}^{25}$ também conhecido como "Padre Mestre": "Mas quem mandou o Padre Mestre fazer-se pedreiro, contrair dividas e calotear depois os seus credores?" E mais a frente: "Para que foi porém que um homem apenas enfarinhado no Latim da primeira Selecta, quis meter-se a fabricante de pão?" (grifo no original). ${ }^{26}$ É evidente a forma irônica como Evaristo referia-se às dificuldades financeiras de Marcelino e ainda insultava sua formação. A verve crítica e irônica de Evaristo manteve-se presente também em outros registros, como por exemplo, nas cartas remetidas ao irmão João Pedro da Veiga, quando da sua única viagem ao sul de Minas de Gerais, poucos dias antes de falecer. Em uma das missivas, embora 0 publicista recusasse-se a falar em política, não deixaria de manifestar certo regozijo em relação à perda de poder da família Breves, informação que provavelmente havia sido dada anteriormente por João Pedro, que ficara na Corte. Evaristo lhe respondeu que "sobre coisas públicas, não desgostei de que os Breves fossem reduzidos a ficarem um pouco mais breves." ${ }^{27}$

Evaristo foi um dos mais importantes representantes do grupo político liberal moderado. Como afirma Marco Morel, nessa época ainda não existia "partido político" no sentido que se tornou corrente em fins do século XIX, nem mesmo na Europa Ocidental. Ao contrário, partidarização tinha conotação pejorativa, sobretudo num momento de afirmação da modernidade e da unidade nacional. Entretanto, o autor ressalva que tais características não precisam conduzir a uma visão negativista, como se não houvesse qualquer forma de organização política. 0 que se denominava partido político constituía-se em formas de agrupamento em torno de um líder, ou através de palavras de ordem e da imprensa, em determinados espaços associativos ou de sociabilidade e a partir de interesses e motivações especificas, além de se delimitarem por lealdades ou afinidades intelectuais, econômicas e culturais entre seus participantes. ${ }^{28}$ De acordo com Lucia Guimarães, os adeptos da moderação careciam de um programa 
Biblioteca Nacional. Cartas de Evaristo Ferreira da Veiga ao irmão João Pedro da Veiga, 02/01/1837, I-02. Para uma análise mais pormenorizada dessas cartas, ver: ANDRADE, Marcos Ferreira de. Família e política nas Regências..., Op. Cit.

28

MOREL, Marcos. O período das Regências (1831-1840). Rio de Janeiro: Jorge Zahar Ed., 2003. p.32.

29

GUIMARÃES, Lucia Maria Paschoal. Liberalismo Moderado..., Op. Cit., p.105.

30

Ver: WERNET, Augustin. As sociedades políticas da província de São Paulo na primeira metade do período Regencial. Tese (Doutorado em História Social). Faculdade de Filosofia, Letras e Ciências Humanas, Universidade de São Paulo, São Paulo, 1975; __ Sociedades Políticas (18311832). São Paulo: Cultrix; Brasilia: INL, 1978. GUIMARÃES, Lucia Maria Paschoal. Em nome da ordem e da moderação: a trajetória da Sociedade Defensora da Liberdade e da Independência Nacional. Dissertação (Mestrado). Instituto de Filosofia e Ciências Socias, Universidade Federal do Rio de Janeiro, Rio de Janeiro, 1990.

31

As Sociedades Defensoras também desempenharam um papel político importante na província de Minas Gerais, como por exemplo, a congênere que foi criada na vila de Campanha, no sul de Minas, e contava com a participação dos dois irmãos de Evaristo que ali residiam. Ver: ANDRADE, Marcos Ferreira de. Família e política nas Regências..., Op. Cit., p.268.

32

Ver: LENHARO, Alcir. As tropas da moderação: o abastecimento da Corte na formação política do Brasil (1808-1842). São Paulo: Símbolo, 1979.

33

Ver: ANDRADE, Marcos Ferreira de. Elites regionais e a formação do Estado Imperial brasileiro...0p. Cit.

34

Princípio criado por Aristóteles, apropriado pelo constitucionalismo inglês do século XVII e mais tarde pelos doutrinários franceses da Restauração. Ver: BASILE, Marcello. 0 Império em construção..., 0p. Cit., p.42.

35

Aurora Fluminense, n.573, 23/12/1831, p.2430.

36

RIBEIRO, Gladys Sabina. Causa nacional e cidadania: a participação popular e a autonomia na imprensa carioca do início dos anos 1830. In: NEVES, Lúcia Maria Bastos Pereira et al. (orgs.) História e imprensa: representações culturais e práticas de poder. Rio de Janeiro: DP\&A, FAPEMIG, 2006. p.129. definido, de documentos públicos sujeitos a verificação e registro. Assim, aponta que não constituiam um grupo coeso, dotado de disciplina partidária, como os que existem nas formações contemporâneas..$^{29} \mathrm{E}$ tal característica pode ser observada em todas as facções do período. Portanto, os enquadramentos políticos entre exaltados, moderados e caramurus devem ser feitos com bastante cuidado, levando-se em consideração o contexto das Regências em que havia vários projetos de nação em disputa e em constante construção, além das trajetórias dos atores envolvidos, os quais nem sempre concordavam com todas as ideias promovidas pelos grupos com os quais se identificavam. Além disso, os indivíduos constantemente transmutavam de uma facção para a outra, embora nesse caso, recebessem a pecha de "vira casaca".

Um indício da força dos moderados é o fato do grêmio patriótico em que se agruparam: a "Sociedade Defensora da Liberdade e Independência Nacional," 30 ter se espalhado por várias províncias, chegando a ter mais de 90 instituições. ${ }^{31}$ Os moderados eram vistos como a expressão política dos interesses econômicos de produtores e comerciantes brasileiros das províncias do Rio de Janeiro, São Paulo e Minas Gerais. Alcir Lenharo analisou a acentuada influência que os fazendeiros e negociantes ligados à economia de abastecimento do Sul de Minas, ou seja, ao comércio de tropas, exerceram na Corte durante a hegemonia liberal moderada do período das Regências. ${ }^{32}$ No mesmo sentido, em sua análise acerca do papel das elites sul - mineiras na construção do Estado Imperial, Marcos Andrade assinalou a relação entre proprietários ligados a um leque diversificado de atividades e o grupo político moderado. 0 autor acompanhou, de perto, toda a trajetória da família Junqueira, que teria um deputado associado ao referido grupo político. ${ }^{33}$

A moderação baseava-se no princípio político adotado na França, do juste milieu, que defendia o equilibrio racional entre os excessos passionais extremos. ${ }^{34}$ Em sua Aurora Fluminense, Evaristo demonstrava que a adoção desse princípio no Brasil, por parte dos moderados, seria mais benéfica e teria maior desenvolvimento que na França. Em parte porque o Brasil era cercado por repúblicas, enquanto os franceses tinham monarcas absolutos como vizinhos.

0 juste milieu, tão agredido e com tanto talento pelos escritores da Oposição na França, o juste milieu que, entendido como o deve ser, corresponde ao nosso princípio da moderação, salvas na prática política as diferenças que cumpre guardar entre um país como o Brasil, livre do caruncho do privilégio, e outro, aonde ele subsiste; entre uma terra Americana, e rodeada de repúblicas, embora nominais algumas delas, e outra, cercada de tronos antigos, e alguns deles tão absolutos como o capricho do homem (....). ${ }^{35}$

Por fim, cabe ainda esclarecermos a maneira como Evaristo da Veiga percebia, ou melhor, representava o quadro político brasileiro do período analisado. Cumpre antes assinalar que essa representação divergia conforme a linha política dos periódicos analisados. Às vezes, dentro de uma mesma facção, havia diferentes interpretações, como era o caso dos exaltados. Eles não eram unânimes. Como assinala Gladys Ribeiro, os jornais rotulados exaltados, tinham propostas bem diferentes entre si e não raro criticavam-se uns aos outros. ${ }^{36}$

Tomemos, como exemplo, o caso de um periódico que se dizia exaltado, mas representava o quadro político brasileiro de forma distinta de seus 


\section{7}

Vários dos periódicos exaltados consultados não acreditavam na existência do grupo Caramuru, ou pelo menos julgavam que os moderados exageravam na extensão de seus membros, com 0 intuito de perseguir os patriotas que fizeram 0 7 de Abril. Por outro lado, e contraditoriamente, julgavam que os caramurus ou restauradores estavam se fortalecendo por culpa dos próprios moderados, como veremos adiante. Ver por exemplo, O Sentinella da liberdade no Rio de Janeiro, n.1, 20/11/1832.

38

O Exaltado, n.1, 04/08/1831, p.2.

39

Aurora Fluminense, n.538, 30/09/1831, p.2273.

40

Identificamos essa divisão com base nas caracteristicas apresentas por BASILE, Marcello Otávio Neri de Campos. O Império em construção..., Op. Cit.

41

Ibidem.
42

BASILE, Marcello Otávio Neri de Campos. Projetos de Brasil e Constituição Nacional na Imprensa Fluminense. In: NEVES, Lúcia Maria Bastos Pereira et al. (orgs.) História e imprensa, Op. Cit., p.68-74. congêneres: 0 Exaltado, em 1831, não declarava a existência dos caramurus $^{37}$ e afirmava atuar quatro "partidos" na cena pública: Os Puritanos ou Exaltados, os Moderados, os Republicanos, e os Federados. 0 redator defendia o grupo Puritano, como o que tinha as propostas mais convenientes para o Brasil. Os Puritanos defendiam o governo monárquico, representativo, vitalício e unitário. Os moderados eram amigos da antiga administração de D. Pedro I e seu sistema de governo era "qualquer um, uma vez que thes prometa vantagens e interesses". Os Republicanos desejavam a "monarquia eletiva e temporária" e os Federalistas queriam cada província "no gozo dos Direitos que lhe são indispensáveis, ligadas entre si, e unidas a um centro comum, isto é à Corte, por tratados com obrigações reciprocas." 38

Já Evaristo tinha outra representação da cena política de seu tempo. Escolhemos uma passagem em que ele confirma as reflexões do periódico Olindense sobre o assunto:

Os brasileiros se encontram divididos, uns querem as leis de exceção, as medidas violentas, a anarquia, a guerra civil; outros almejam à restauração e o império de $D$. Pedro; outros querem a Constituição com todos os seus pontos e vírgulas, repelem toda reforma, desejam sustentar a todo custo o elemento monárquico e a dependência das Províncias; outros querem a Constituição, mas a Constituição acomodada às circunstancias do Brasil, com as modificações e reformas que a opinião pública tão altamente pede e ela (a Constituição) autoriza. ${ }^{39}$ (Grifos nossos)

No trecho acima percebemos a atuação de quatro grupos políticos: 0 anárquico - epíteto com o qual eram tratados os exaltados; o caramuru que repelia as reformas; o restaurador - que desejava a volta de D. Pedro; e o moderado - indicado como aquele que atenderia aos interesses da opinião pública, mas na forma da lei. ${ }^{40}$ Contudo, nem sempre Evaristo fazia distinção entre caramurus e restauradores, provavelmente para aumentar a aversão com relação aos primeiros. De acordo com Marcello Basile, nem todos os caramurus eram restauradores, embora todos os restauradores fossem caramurus. ${ }^{41}$

A seguir passaremos a examinar os embates entre os distintos grupos políticos regenciais e as representações feitas pelos adversários de Evaristo na imprensa periódica, particularmente pelos jornais exaltados. $E$, de antemão, afirmamos a impossibilidade de se separar o indivíduo político do grupo de cujos ideais comungava. Assim, mesclaremos as representações que os grupos contra-hegemônicos faziam de Veiga e do governo moderado.

\section{Os embates e as representações de Evaristo por parte de seus adversários políticos}

De acordo com Marcello Basile, os exaltados eram adeptos de um liberalismo mais radical. Defendiam tanto a igualdade jurídica como também a social, seguindo os preceitos de Rousseau. Para esse grupo, cidadão era toda pessoa livre, homem ou mulher, podendo votar em todas as eleições para as Assembleias e ser eleito, caso tivesse virtude e talentos. Ao admitirem a mulher na cidadania política iam além das práticas políticas vigentes em todo o mundo, inclusive durante a Revolução Francesa. Os exaltados combatiam o preconceito racial, defendendo a efetiva integração dos negros e mulatos livres e libertos à nação. Mostravam-se contrários ao sistema escravista, mas nem por isso defendiam a abolição imediata. ${ }^{42}$

Por outro lado, os exaltados eram marcados por um forte antilusitanismo, o qual se demonstrava em seus jornais, por meio da crítica à ampla 
43

Idem, p.76-79.

44

Para maiores informações sobre a biografia do redator, ver: BASILE, Marcello. 0 Império em construção..., Op. Cit., p.141.

45

A Matraca dos Farroupilhas, n.1, 22/11/1831, p.1.

46

Ibidem.

47

lbidem.

48

Ibidem.

49

Ibidem. Esses indivíduos eram áulicos de D. Pedro I.

50

Ibidem.

51

0 direito de petição estava previsto na

Constituição de 1824, mas ela deveria ser feita de forma pacífica.

52

Ver maiores detalhes em BASILE, Marcello. 0 Império em construção..., Op. Cit., p.260-277. presença de portugueses no comércio e cargos públicos e da crença de que os mesmos constituiam uma ameaça à nacionalidade, suspeita que recaía até mesmo nos adotivos. Qualificavam de despótico, tanto o governo de D. Pedro como o Regencial, e pregavam abertamente a revolução, como forma única de garantir a liberdade da nação. Marcello Basile afirma que os jornais exaltados da Corte eram majoritariamente republicanos e todos federalistas, defendendo a criação de Assembleias provinciais e a elegibilidade dos presidentes de província. Diferentemente dos moderados, acreditavam que a soberania da nação estava no povo ou na expressão da vontade geral, enquanto aqueles defendiam que ela residia no Parlamento, pois o povo delegava aos seus representantes, a soberania que a princípio detinha. ${ }^{43} \mathrm{~A}$ maioria dessas características gerais foram encontradas nas folhas exaltadas que consultamos, mas é problemática a afirmação de que os exaltados defendessem em uníssono a federação. Aliás, como já demonstrado acima, nem mesmo os moderados que estavam no poder tinham ideias uniformes, basta citar a tentativa de golpe de Estado em 1832, que acabou sendo frustrada por não contar com o apoio de todos os membros do grupo.

No primeiro número, e cumprindo a promessa que fizera no seu extinto Jurujuba dos Farroupilhas, o redator de A Matraca dos Farroupilhas, João Baptista de Queiroz, ${ }^{44}$ analisou o discurso da Regência Permanente ao encerrar a Sessão do Corpo Legislativo. Queiroz parte da seguinte afirmação presente no discurso da Regência: "No momento em que termina a presente Sessão os negócios de Estado oferecem um aspecto menos desagradável aos amigos das liberdades públicas!"45 Em seguida, levantou a hipótese de que o governo estivesse sem notícias oficiais dos desastres ocorridos no Pará, onde "os Brasileiros influentes para a Proclamação da Independência naquela Província em 1822", ${ }^{46}$ sofriam violências. Mas logo apontou que as ditas violências foram louvadas no Diário do Governo, alguns dias depois do discurso da Regência, o que demonstrava que o governo era conivente com as mesmas. A partir daí relembrou o "dia infeliz" ${ }^{47}$ de 14 de Julho, e a "sessão de três dias"48 com "os grandes escarcéus que fizeram os canibais de moderação fingida só para evitar que Valente, Anemuria, Paranaguá e Baependi, fossem comer na Europa o soldo que se Ihes dava." ${ }^{49}$ Enfim, passou a acusar a falta de patriotismo do Governo e do Corpo Legislativo, em razão da diferente conduta que tiveram por ocasião dos dois acontecimentos e concluiu, sem deixar de atacar Evaristo: "Se tivéramos recebido da natureza o dom de envenenar tudo, como faz o Aurora, diriamos que hoje é virtude oprimir brasileiros e um crime imperdoável não ter amor à gente do antigo Gabinete Secreto." 50

Os acontecimentos do dia 14 de Julho a que se refere A Matraca dizem respeito a uma representação enviada ao governo, pedindo a deportação de oitenta e nove pessoas, entre as quais constavam várias personalidades políticas do reinado de $D$. Pedro I e a suspensão por 10 anos da emigração ordinária dos portugueses. A representação foi submetida às Comissões de Constituição e Justiça Criminal da Câmara dos deputados e afinal considerada inconstitucional, posto que a petição $0^{51}$ fora feita pelo Povo e Tropa com armas nas mãos. ${ }^{52}$ Ao negarem a execução da representação, os deputados moderados, entre eles, Evaristo da Veiga, passaram a ser acusados de proteger os portugueses "festeiros de Março" e perseguir os brasileiros patriotas. 0 periódico, conforme pode ser observado na citação abaixo, pronunciar-se-ia de tal modo, e ainda buscaria redarguir a acusação do "Sr. Evaristo Aurora", de ser "partidista de Exércitos Perma- 
53

Referência aos conflitos entre portugueses e brasileiros que ficou conhecido como "Noite das Garrafadas". Ver: RIBEIRO, Gladys Sabina. A liberdade em construção: identidade nacional e conflitos antilusitanos no Primeiro Reinado. Rio de Janeiro, Relume Dumará, 2002.

54

A Matraca dos Farroupilhas, n.1, 22/11/1831, p.4.

55

O Clarim da Liberdade, n.7, 07/12/1831, p.41-42.

56

Idem, n.9, 14/12/1831, p.53.

57

Ibidem, p.54

58

Ibidem.

59

Conforme o jornal Caramuru o redator de 0 Clarim da Liberdade era José Luiz Ferreira. Ver: BASILE, Marcello. O Império em construção..., Op. Cit., p.141.

60

O Clarim da Liberdade, n.9, 14/12/1831, p.54. nentes", tratando os militares brasileiros da mesma instituição, como "os bravos de 6 de Abril":

0 matador capitalista armado para oprimir e roubar é ainda mais temivel à Liberdade, do que os bravos de 6 de Abril. 0 que lamenta a Matraca é a cilada que se armou aos brasileiros militares de 6 de Abril, armando os Festeiros de Março, ${ }_{1}^{53}$ que andaram de faca de ponta nos desastrosos dias de Maio, talvez por manobra dos ingratos e traidores ao Exército de 6 de Abril. ${ }^{54}$

Evaristo foi representado como um traidor dos militares que participaram do movimento que levou à abdicação de D. Pedro I e como um capitalista armado para oprimir e roubar. Essa última representação está também presente em outras folhas exaltadas. Nesse sentido, transcrevemos parte de uma correspondência inserida em 0 Clarim da Liberdade, assinada por "0 Carioca":

Forte mania é a dos brasileiros persuadirem-se que em sua terra podem vestir a seu gosto e segundo suas fantasias, sem primeiro obterem licença dos capitalistas, nova espécie de aristocracia, à cuja vontade nós devemos curvar, porque se acha apoiada pelo chefe do partido intitulado da moderação, hoje ligado com o português. Ora com efeito não se dá maior escândalo, havendo bons chapéus Portugueses e Ingleses, que um punhado de brasileiros se animem a usar chapéus de palha, que estão proscritos desde as noites de Março, e que a Aurora também não gosta deles, embora o digno redator do Patriota, jovem de grandes esperanças, se esforça com razões sólidas a sustentar quanto será vantajoso sustentar a indústria nacional. Eu de minha parte, Sr.Redator, estou isento felizmente desta mania, e não pretendo usar semelhantes chapéus, para não sofrer algum dixote de gente bem educada toda capitalista, e evitar assim a violar os decretos da Aurora, e desgostar essa gente, a quem tanto respeito depois das ameaças. ${ }^{55}$ (Grifo no original)

A partir da citação acima, eram considerados capitalistas aqueles envolvidos direta ou indiretamente na venda de produtos importados e não interessados no desenvolvimento da produção nacional. 0 chapéu de palha, portanto, era mais do que um acessório distintivo para os exaltados, representava, outrossim, a defesa de uma maior independência econômica com relação a outros países.

Nas folhas exaltadas, Evaristo era o moderado mais combatido. 0 Clarim e outros chegam mesmo a considerar Veiga como o "chefe do partido moderado." ${ }^{56} \mathrm{Na}$ ocasião, o periódico ainda acusou o redator da Aurora de reconhecer em seu número 567, que "a revolução do 7 de Abril recebera a direção e impulso principal da cabeça, e braço de cidadãos que não pertenciam à sua comunhão política. ${ }^{57}$ Assim, os exaltados se representavam como aqueles que fizeram a revolução com seus próprios "braços", enquanto os moderados, "os cabeças", deram direção e impulso ao 7 de Abril, para "poderem, como de fato o fizeram, lucrar com a revolução." ${ }^{58}$ No mesmo artigo, o redator do Clarim ${ }^{59}$ respondeu à acusação da Aurora, de que os exaltados é que agrediram inicialmente aos moderados:

Nós temos visto o terror, o insulto, os crimes perpetrados pelo partido moderado depois do 7 de Abril, dia Sagrado, bem que infeliz, temos visto prisões arbitrárias, devassas ilegais, perdão aos malvados, vemos presos o Sr. Honório sem crime, vimos os Senhores Tupinambá e Cunha, presos em virtude de testemunhas falsas, os Senhores Bacellares em masmorras por detestarem os portugueses, o Sr. Frias por se dizer o Redator da Voz da Liberdade, os Senhores Rangel e Pimentel perseguidos, os Senhores Juvêncio etc. ${ }^{60}$ 
61

Referência a alguns juizes de paz, que assim se mostravam. Entre eles, João Pedro da Veiga, irmão de Evaristo e que residia na Corte.

62

Exaltados.

63

0 redator.

64

O Jurujuba dos Farroupilhas, n.6, 26/09/1831, p.46. O Jurujuba era escrito por João Baptista de Queiroz, antes do mesmo iniciar a redação da Matraca.

65

MOREL, Marco. 0 periodo das Regências..., Op. Cit., p.21.

66

O Jurujuba dos Farroupilhas, n.10, 07/10/1831, p.73-75.

67

Referência à rebelião escrava haitiana que levou à independência da Colônia francesa de São Domingos, em 1790, e resultou no massacre de uma enorme população branca da ilha. Ver: JAMES, Cyril Lionel Robert. Jacobinos Negros:

Toussaint L'ouverture e a renovação de São Domingo. São Paulo: Boitempo, 2000.

68

REIS, João José. Rebelião escrava no Brasil: a história do levante dos malês em 1835. São Paulo: Companhia das Letras, 2003. p.534.

69

Ver: ANDRADE, Marcos Ferreira de. Elites regionais e a formação do Estado Imperial brasile... Op. Cit. p.298-321. REIS, João José. Op. Cit.

70

0 problema da escravidão não foi um tema muito recorrente nas matérias impressas nos jornais moderados, incluindo a Aurora Fluminense, embora esta tenha se dedicado um pouco mais sobre o assunto. Para uma discussão mais detalhada sobre a questão ver: BASILE, Marcello. O Império em construção..., Op. Cit.; ANDRADE, Marcos Ferreira de. Imprensa moderada e escravidão: o debate sobre o fim do tráfico e temor do haitinismo no Brasil Regencial (1831-1835). Anais do 4 Encontro Escravidão e Liberdade no Brasil Meridional. Curitiba, Universidade Federal do Paraná, 13 a 15 de maio de 2009. p.1-25. Disponivel em: http://www. escravidaoeliberdade.com.br/site/images/Textos4/ marcosferreiradeandrade.pdf. Acessado em: 20/03/2012.
Por meio dessa citação percebe-se como os exaltados justificavam o rompimento com os moderados depois do 7 de Abril. Os moderados é que teriam sido os responsáveis pela cisão entre os dois grupos, pois passaram a perseguir os exaltados por meio de prisões ilegais e sem crime, e ainda desrespeitando a liberdade de imprensa. Os moderados eram tratados

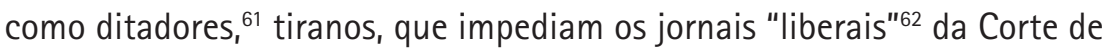
chegarem às províncias e interceptavam correspondências, como é possível perceber em uma das várias denúncias publicadas em 0 Clarim: "já outro dia o Sr. Castro Álvares disse na Câmara que recebera uma carta aberta, e eu mesmo ${ }^{63}$ tenho recebido cartas de Pernambuco, misturadas com as da Bahia, e com atraso de um paquete" ${ }^{64}$.

0 que estava em jogo não era somente a divisão entre moderados e exaltados em torno do significado político do 7 de Abril e dos grupos que o desencadearam, mas também da direção política moderada que passaria a se imprimir a partir de então. Na luta travada pelos grupos para dominar a cena política, ganhou destaque o significado dado ao termo "revolução", utilizado particularmente após o 7 de Abril, e que adquiriu conotações distintas, apropriadas de acordo com a perspectiva de cada grupo político. Segundo Marco Morel, os três principais grupos (caramurus, moderados e exaltados) eram incapazes de negar o caráter revolucionário atribuído ao 7 de abril, mas com acepções bastante distintas. Os caramurus procuravam esquecê-la ou negá-la, uma vez que o Imperador fora deposto; os liberais moderados confirmavam a sua ocorrência, mas justificavam a necessidade de concluí-la em nome dos princípios da moderação. Já os exaltados definiam o 7 de Abril como um processo revolucionário que apenas fora iniciado, mas que ainda não havia sido concluído. ${ }^{65}$

Os moderados eram também apresentados como aqueles que recebiam instruções secretas da "Santa Aliança" para causarem discórdias entre os distintos grupos sociais, e assim conseguirem instalar no Brasil as famílias aristocráticas arruinadas da Europa:

Convém, disse mais a Santa Aliança, que cada um desses partidos tenha seu haitianismo às ordens, convém que se pregue a divisão entre natos, adotivos, para que uns matem os outros, e os nossos estrangeiros cresçam e ajudem a família Orleans a estabelecer tronos na América, conforme as instruções secretas de Calmon com seus amigos... Convém que alguns pardos e caboclos se finjam republicanos de tanga e alfanje, e manobrem haitianismo, e forte perseguição aos chumbos, que estão ao nosso soldo com os de Pedro. ${ }^{66}$

0 fantasma do "haitianismo," ${ }^{67}$ aludido acima, rondava o interior das casas-grandes, dos principais núcleos urbanos com grande contingente cativo e pairava na mente das autoridades policiais e políticas e também poderia ser instrumentalizado de acordo com os interesses dos distintos grupos políticos. Como afirma João José Reis, o "haitianismo" constituía "um desses pesadelos senhoriais que retornavam a cada rumor de revolta, não só no Brasil, mas em toda a América escravocrata." 68

Esse temor tendia a se agravar em contextos de ousadia e rebeldia escrava, como aconteceu em Carrancas, Minas Gerais, e em Salvador, na Bahia. ${ }^{69}$ Mas foi especialmente após a revolta dos Malês, em janeiro de 1835, que as referências ao "haitianismo" começaram a ser mencionadas com alguma frequência nas folhas da Aurora. ${ }^{70} \mathrm{~A}$ entrada constante de cativos e a ilegalidade do tráfico após a aprovação da lei de 1831 e, sem dúvida, a rebeldia escrava, contribuíram para que a lembrança da revolta 
71

Aurora Fluminense, n.1019, 23 de fevereiro de 1835
72

Idem, n.1032, 27 de março de 1835

73

Idem, n.1034, 01 de abril de 1835.

74

MOREL, Marco. 0 período das regências..., Op. Cit., p.38. de São Domingos fosse associada aos rumores e às revoltas escravas que de fato ocorreram durante as Regências. Mas essas associações têm que ser interpretadas com cautela, uma vez que eram utilizadas de acordo com os interesses políticos em disputa e o prelo constituía o espaço mais que conveniente para difundir e fomentar boatos em torno da instrumentalização dos cativos e/ou pardos e referências ao "haitianismo". 0 temor causado pelos acontecimentos da Bahia recomendava a vigilância, e o surgimento de boatos de que algo semelhante estava para acontecer na capital do Império, só reforçava a recomendação do redator da Aurora.

Tem corrido o boato de que alguma coisa se tenta no Rio de Janeiro, de análogo ao que sucedeu na Bahia. Cuidamos que o temor exagera as suspeitas: mas em objeto tão melindroso, não é perdida toda a vigilância da parte das autoridades. Nós ousamos chamar sobre esta matéria a atenção do Exm. Ministro da Justiça e do Sr. Chefe da Policia. ${ }^{71}$

Em uma mensagem da Assembleia Provincial do Rio de Janeiro dirigida ao Governo Central, datada de 17 de março de 1835 e publicada na Aurora dez dias depois, a revolta dos Malês foi interpretada como consequência da difusão de doutrinas haitianas e semelhante perigo não estava restrito à Bahia, mas também rondava a Corte, sendo levado a cabo por sociedades secretas.

A todos consta que as doutrinas Haitianas são aqui pregadas com impunidade; que os escravos são aliciados com o engodo da liberdade, e concitados por espíritos vertiginosos, nacionais e estrangeiros, dentro e fora da Província, para romper nas mesmas comoções, de que estão os da Bahia dando funestíssimo exemplo: que há na Corte Sociedades secretas que trabalhão sistematicamente nesse sentido; que têm cofres para os quais contribui grande numero de sócios de cor, livres e cativos; que desses cofres saem os subsídios com que se entretêm e mantêm emissários, encarregados de propagar doutrinas subversivas pelos escravos das fazendas de lavoura, onde se introduzem a titulo de mascates ou pombeiros! Os membros dessas Sociedades, e seus fautores, nacionais e estrangeiros, são indigitados pela voz publica... e todavia parece que a Administração policial da Corte ou tudo ignora, ou estranhamente descuidada dorme sobre a cratera do vulcão! E entretanto o incêndio já lavra perto da porta! $!^{72}$

A publicação da mensagem gerou um mal-estar entre os grupos políticos, especialmente entre os moderados, pois, a tomar como verossímil a argumentação do redator no número seguinte, 0 alarde acerca da propagação das doutrinas haitianas estaria diretamente associado ao favorecimento da candidatura de Diogo Feijó, sendo, portanto, uma invenção dos moderados. Tal associação era feita pelos jornais opositores à Aurora e seu redator rechaçou tais argumentos afirmando que a "Moderação não é cúmplice das desordens promovidas por seus inimigos: não; a Moderação não responde pelos desatinos desses que amaldiçoam a sua obra." 73

A instrumentalização dos cativos ou a difusão do temor ao "haitianismo", em momentos de disputas entre elites, não constitui nenhuma novidade, seja em conflitos de caráter mais restrito, envolvendo as disputas locais, ou mesmo em contextos mais amplos das rebeliões ocorridas nas províncias, particularmente no periodo das Regências. Como afirma Marco Morel, a "presença das camadas pobres nas lutas políticas era resultado de um jogo de mútuas tentativas de manipulação e apropriação: constantemente a atividade política escapava ao controle dos grupos privilegiados." 74 
75

Escritório Técnico do IPHAN de São João Del-Rei, Processo-crime de Insurreição (1833), caixa PC 29-01. Depoimento de Maria Joaquina do Espírito Santo, fls. 49. Ver: ANDRADE, Marcos Ferreira de. Elites regionais e a formação do Estado Imperial brasileiro...0p. Cit., p.306.

76

SODRÉ, Nelson Werneck. História da imprensa no Brasil. 4a. ed. (atualizada). Rio de Janeiro: Mauad, 1999. p. 124.

77

O Evaristo, n.4, 19/10/1833, p.02.

78

GUIMARÃES, Lucia Paschoal. Liberalismo moderado..., Op. Cit., p.118-121; FILHO, Arnaldo Fazoli. O Período Regencial. São Paulo: Ática, 1990

79

BASILE, Marcello. O Império em construção..., Op. Cit., p.138-139.

80

De acordo com a denominação judicial da época, um atentado contra a vida era também chamado de assassinato, mesmo que a vítima não falecesse.
Essa constatação pode ser verificada na Revolta de Carrancas, ocorrida no dia 13 de maio de 1833, nas propriedades da família Junqueira, quando nove integrantes da família foram mortos pelos escravos. Os cativos rebeldes também se apropriaram, à sua maneira, do contexto de disputas políticas dos anos iniciais das Regências, inclusive incorporaram os apelidos que os membros das elites utilizavam para enquadrar ou estigmatizar seus oponentes. 0 depoimento de uma das testemunhas é revelador desse tipo de apropriação. Quando o grupo de rebelados dividiu-se e partiu para a fazenda Jardim, liderados por Ventura Mina, ao passar pela casa de uma agregada, depois de ameaçá-la e exigir que entregasse as armas que possuía, o preto Antônio Benguela "pulava no seu terreiro e batia nos peitos dizendo para ela e seu companheiro vocês não costumam falar nos Caramurus, nós somos os Caramurus, vamos arrasar tudo..."75

De outro modo, os moderados eram ainda comparados aos jacobinos da Revolução Francesa. É o que fez o pasquim O Evaristo, que circulou em apenas cinco números. De acordo com Nelson Werneck Sodré, havia uma tênue diferença entre os periódicos e pasquins, sobretudo no que diz respeito à continuidade e estabilidade. Em geral, os pasquins surgiam em tempos de lutas políticas intensas e violentas e sua linguagem era insultuosa, com o objetivo de ferir os seus contrários e perdê-los no conceito público. ${ }^{76} 0$ Evaristo censurava a administração e o grupo moderado como um todo, apesar de seu título causar a impressão de que as críticas seriam direcionadas apenas a Evaristo da Veiga. Mas esse aspecto vem reforçar o que já afirmamos anteriormente, ou seja, sobre a dificuldade de se separar o indivíduo em questão, de seu grupo, graças à posição de destaque que lhe era conferida no mesmo. Assim se exprimia o mencionado impresso: "Pensaram acaso os Jacobinos que o assassino do redator do Brasil Aflito, a prisão do honrado e corajoso cidadão Maurício José de Lafuente, será capaz de infundir o terror no nobre Partido Exaltado, desprezador dos maiores perigos?" 77

Ainda é importante mostrarmos como os exaltados referiam-se ao golpe de 30 de Julho de 1832, tramado por parte do grupo moderado. A pretensão era converter a Câmara dos deputados em Assembleia Nacional e assim abrir caminho para a adoção da chamada Constituição de Pouso Alegre. 0 motivo do golpe era o fato das reformas constitucionais defendidas serem proteladas pelo Senado. Como apontado anteriormente, a tentativa causou dissensões entre os próprios moderados, o que comprova a falta de coesão entre eles. ${ }^{78}$ Para referirmo-nos ao acontecimento, citaremos uma passagem de 0 Sentinella da Liberdade do Rio de Janeiro, cujo redator era o mulato Joaquim Candido Soares Meirelles, que por sua vez, dizia-se discípulo de Cipriano José Barata de Almeida, o mais renomado líder exaltado. ${ }^{79} \mathrm{Na}$ mesma ocasião, 0 Sentinella fez referência ao atentado sofrido por Evaristo da Veiga e à sua atuação na Sociedade Defensora, o grêmio dos moderados:

\footnotetext{
Ora, é constante que o assassinado ${ }_{1}^{80}$ postergando todas as leis da decência, e do decoro tem dirigido as mais insultuosas expressões e ditérios infamantes a cidadãos probos e virtuosos (...) chegou a tal ponto sua perversidade e baixos sentimentos, que vilipendiou atrozmente em a Sociedade Defensora, a uma classe de homens, a qual talvez pertença (...). Este mesmo homem lançou a intriga entre Brasileiros adotivos, e exaltados, dizendo a aqueles que estes queriam roubar suas propriedades (...) em suma para a Aurora, antes de 30 de Julho, aqueles eram proprietários que nada ganhavam com revoluções, eram capitalistas, amigos da ordem e etc.; em 30 de Julho, porque os adotivos não estiveram pela república de tanga e alfanje, são
} 
O Sentinella da Liberdade do Rio de Janeiro, n.1, 20/11/1832, p.2-3.

82

Em seu inicio, a Sociedade Defensora funcionava como uma organização suprapartidária e nela conviviam moderados, exaltados e futuros caramurus. WERNET, Augustin. Op. Cit., p.75.

83

BASILE, Marcello Otávio Neri de Campos. Projetos de Brasil e Constituição Nacional..., 0p. Cit., p.80-89.

84

Marcello Basile aponta que o redator não possuía esse título. Seu nome era Augusto Hugo Auf Hoiser e nasceu em Hanover, na Alemanha. BASILE, Marcello. O Império em construção..., Op. Cit., p.339.

85

0 Carijó, n.3, 17/01/1832, p.3-4.

86

Idem, n.43,14/02/1833, p.187.

87

Ibidem. restauradores, querem a volta de D. Pedro: não são porém restauradores, aqueles que outrora eram criaturas de D. Pedro e que hoje são empregados! ${ }^{81}$

0 trecho acima praticamente culpa Evaristo da Veiga de seu próprio atentado, pois o mesmo difamava cidadãos, o que era muito grave para a época, e transformou a Sociedade Defensora em uma entidade privativa. ${ }^{82}$ Além disso, o redator deixou explícita a participação de Evaristo no golpe de 30 de Julho e ainda o acusava de tratar os adotivos de forma diferente, após essa ocasião. Antes, mostrava-se amigo dos adotivos e colocava-os contra os exaltados. Depois, em virtude de não ter tido o apoio dos mesmos para o golpe, começou a tratá-los como restauradores, enquanto os antigos servidores fiéis de D. Pedro, não eram assim considerados. Essa postura sugere que o redator exaltado pretendia alcançar o apoio dos brasileiros adotivos e colocá-los contra os moderados.

Mas se os exaltados tentavam colocar os adotivos contra os moderados, quem dirá os caramurus. Os caramurus eram partidários de um liberalismo conservador, com postulados clássicos (representação, divisão de poderes, direitos de cidadania) sem abrir mão de um Estado forte, centralizado e reticente a reformas. 0 tipo de Governo almejado pelos caramurus era 0 mesmo firmado pela Constituição de 1824 e vigente no Primeiro Reinado. Os caramurus também não formavam um grupo homogêneo, pois somente alguns de seus componentes pregavam abertamente a restauração de D. Pedro I e o seu retorno para o Brasil. Defendiam um projeto político firmado sobre uma soberania que não residiria no povo ou no monarca, mas no contrato social, violado com as reformas constitucionais de $1834 .^{83}$

Assim, o redator de 0 Carijó, o Barão de Bulow, ${ }^{84}$ transcreveu um artigo do Mensageiro da Bahia, que relatava sobre uma revolta na capital da província de Goiás, cujo objetivo era depor os brasileiros adotivos de seus empregos. 0 redator apontou que o Governo estava informado do caso, mas pouco poderia fazer naquele momento. Deveria antes "examinar o estado das Províncias e o espírito do Povo, a fim de se pouparem novidades semelhantes, que trazem o cunho da precipitação e da injustiça." ${ }^{5}$ Além de culpar os moderados pelos infortúnios dos adotivos, o periódico ainda os acusava de não terem consideração pelos homens de cor, critica que vez ou outra também aparecia nas folhas exaltadas. E 0 Carijó questionava: "Por outro lado quais são os homens de cor a quem o intruso atual governo tenha despachado? Nenhum, segundo nos consta." ${ }^{86}$ Além disso, mostrava como D. Pedro I era bem mais benevolente com o mesmo extrato social, pois "recompensou o mérito, sem Ihe importarem as cores dos indivíduos. Elevou às altas dignidades de Marqueses, e Senadores a vários homens de cor, e condecorou com o hábito de Cristo a muitos outros." ${ }^{87}$ Conforme assinalamos anteriormente, a instrumentalização da população de cor por parte dos distintos grupos políticos foi recorrente no contexto das Regências. Os exaltados, caramurus e moderados tentavam instrumentalizar essa população contra os seus oponentes de acordo com os seus interesses e 0 contexto de disputas políticas em jogo, mas muitas vezes poderiam escapar ao controle desses grupos privilegiados.

Apesar de sempre fazer comparações favoráveis ao governo de D. Pedro I, em relação ao moderado, 0 Carijó afirmava não ser restaurador: "francamente declaramos que não é intenção nossa advogar a favor da restauração do Sr. D. Pedro I, mas sim mostrar a nulidade da sua abdicação, afim de que o nosso Amado Jovem Monarca o Sr. D. Pedro II, possa evitar iguais maqui- 
89

Idem, n.27, 05/07/1832, p.111.

90

Ibidem.

91

Ibidem.

92

Ibidem.

\section{3}

Em Março-Abril de 1831, no desenrolar do episódio da Noite das Garrafadas.

94

0 Carijó, n.26, 30/06/1832, p.108.

95

BASILE, Marcello. O Império em construção..., Op. Cit., p.337.

96

0 Caramuru, n.20, 05/09/1832, p.4.

97

Idem, n.3, 10/03/1832, p.1.

98

O Verdadeiro Caramuru, n.10, 21/06/1833, p.1 nações e desgraças." ${ }^{88} 0$ redator defendia que 07 de Abril, "não se pode qualificar como uma revolução," 89 mas sim uma "revolta contra o chefe de Estado." ${ }^{100} \mathrm{E}$ apontou ter sido um erro gravíssimo por parte dos representantes da Nação, "fazer Regentes aos mesmos que estavam à testa da revolta contra D. Pedro I, quando todos eles tinham a reputação de Republicanos (...)."191 Dessa forma, 07 de Abril era visto como um movimento republicano, assim como os Regentes e todos os que participaram do movimento, entre eles, os moderados. No mesmo artigo fez referência a Evaristo questionando se alguma vez, no reinado de D. Pedro I, viu-se que "um Livreiro, por desgraça do Brasil, insultasse o Povo nas galerias." ${ }^{92}$ Com isso demonstrou o seu desprezo com relação à profissão de Veiga.

Evaristo era representado como aquele que insultava o Povo e que sempre pedia sangue. Expressava-se da seguinte forma: "o Sr. Deputado Ferreira da Veiga, pedia então o sangue português, ${ }^{93} \mathrm{em}$ Outubro dos Brasileiros, e agora pede o de todos aqueles que não são moderados (...). ${ }^{194}$ Ademais, os caramurus constantemente buscavam desacreditar Evaristo enquanto líder político, demonstrando a sua inconstância, falta de opinião e caráter. É o que destacaremos de $O$ Caramuru, cujo redator era David da Fonseca Pinto. ${ }^{95} \mathrm{Em}$ setembro de 1832, o redator dedicou um exemplar inteiro para apontar as contradições de Evaristo, antes e depois do 7 de Abril. Deu ao longo artigo o título de "Evaristeida", do qual extraímos a seguinte passagem:

Antes de 7 de Abril, nessa Aurora 251; cujo extrato acima publicamos, se vêem os maiores elogios ao Sr. D. Pedro I por ter sido eleito por unânime aclamação dos povos, censurando-se aí o princípio da legitimidade a que o Sr. Evaristo chama famoso absurdo; em Junho do corrente, falando o Sr. Evaristo da esquadra do Sr. D. Pedro I contra o Sr. D. Miguel, diz que aquele vai tirar uma coroa a seu irmão, depois de ter tirado outra a seu pai; logo, ou deve subsistir o mero princípio da legitimidade, e então é contestado o da unânime aclamação dos povos, ou vice-versa (...). ${ }^{96}$

O Caramuru também não aceitava a imputação de ser restaurador e planejar uma revolução para o retorno do monarca abdicado. 0 redator explicava que os elogios feitos a D. Pedro I eram "filhos da nossa convicção, porém sua abdicação voluntária, levou ao Trono, o nosso querido e inocente Imperador o Sr. D. Pedro, a quem defenderemos sempre, respeitando a Regência que em seu nome delibera (...)." ${ }^{17}$ Interessante como David colocou que a abdicação de D. Pedro não fora forçada por nenhuma revolução, mas voluntária, e ainda se comprometeu a respeitar a Regência, porém certamente não os homens que estavam juntamente com ela, no poder.

Em relação ao periódico 0 Verdadeiro Caramuru, cujo redator não pudemos identificar, ressaltamos a representação feita acerca da Sociedade Defensora, enquanto uma potência, que não sendo nenhum dos poderes políticos da Constituição, os governa e os dirige, segundo dizem e se prova." ${ }^{198}$ Em seguida, o redator denunciou o poder exorbitante da agremiação. Seus membros seriam preferidos para os cargos do judiciário, mesmo não tendo as "luzes" suficientes e na legislatura tinham enorme influência. 0 redator sarcasticamente fez ainda um trocadilho para ilustrar o poder de seus membros: "O Poder Moderador suspeita-se, não terem podido atraí-lo; mas ou para se darem importância, ou para rebaterem-lhe a consideração, assentaram em se denominarem Moderados; e é talvez daqui que lhe provém o orgulho de suporem suas pessoas invioláveis e sagradas." ${ }^{199}$ Com esse texto, o autor parece querer indigitar a opinião pública contra os membros da Defensora, mostrando que exerciam atribuições que não Ihe pertenciam de direito. 
100

D. Pedro I, n.2, 07/09/1833, p.3.

101

Aurora Fluminense, n.834, 28/10/1833, p.3557.

102

Ibidem.

103

BASILE, Marcello. O Império em construção..., Op. Cit., p.35-36.

104

O Sete d'Abril, n.4, 10/01/1833, p.2.

105

Idem, n.5, 15/01/1833, p.1-4.

106

Ibidem.

107

Ibidem.

108

Ibidem.

109

Ibidem.
Ainda é importante ressaltar que os impressos exaltados e caramurus que analisamos, embora tivessem suas diferenças, às vezes usavam das mesmas armas em suas lutas contra os moderados, por exemplo, atiçando o ódio de adotivos e homens de cor contra o governo e autoridades moderadas. Em nossa análise, constatamos que esses dois grupos (exaltado e caramuru) não se enfrentavam, ou pelo menos não o faziam frequentemente. No pasquim D. Pedro I, de autoria desconhecida, encontramos inclusive, uma espécie de pedido desesperado pela união entre Exaltados, Caramurus e Moderados de "boa fé", que ainda tinham tempo de voltar à "luz da razão." 100 Mas o convite aos primeiros é que nos faz pensar que os caramurus estavam mesmo com uma vontade muito "exaltada" de destruir o domínio moderado. Isso porque representava o pedido de um grupo formado pelos homens de "maior propriedade e saber" feito aos que criticavam capitalistas e aristocratas. De acordo com Evaristo, a união entre exaltados e caramurus: "É liga de matérias repugnantes, cuja solda única está na aversão que todos votam ao poder atual." ${ }^{101}$ Vejamos:

\begin{abstract}
Mancebos incautos, vós que existes no partido exaltado, não abraceis a nuvem por Juno e vinde às nossas fileiras. Se buscais a liberdade, vós encontrareis em nossos braços seus mais fortes defensores. Atentai bem para nossa parte, e vede quais são os homens que formam nosso partido, a que os sicofantas apelidam Caramuru, Restaurador e escravo, aqui achareis os maiores proprietários, anciões respeitáveis por suas virtudes e saber, e enfim as classes mais úteis do Estado. Unamo-nos portanto patrícios, porque só desta sorte poderemos salvar o Brasil. ${ }^{102}$
\end{abstract}

Por último trataremos das representações de um periódico identificado ao grupo moderado, $O$ Sete d'Abril, acerca de Evaristo e seus aliados internos do "partido". Embora se afirmasse moderado, 0 Sete d'Abril mantinha um discurso crítico e virulento acerca de Veiga e de outros moderados. 0 periódico é tido como obra de Bernardo Pereira de Vasconcellos, o qual, se não participou diretamente de sua redação, certamente orientou a linha doutrinária do mesmo. ${ }^{103}$ Já em seus primeiros números, 0 Sete d'Abril apresentava-se aversivo em relação à Aurora. Fazendo-se passar pela "revolução do 7 de Abril", ele critica a Aurora e seus conselhos de moderação, que lhe fizeram perder as forças:

Sara D. Aurora_Quem Ihe pediu conselhos! É forte teima! Vm. não deixará de perseguir-me com as suas moralidades! __ Quando eu era forte e valente; quando eu cuidava derramar sobre o meu caro Brasil todas as bênçãos da regeneração, os seus conselhos de água morna, de contemplações de prudência mulheril, me fizeram perder o meu brio, a minha sublime missão, e agora que todo exangue, e semimorto, vejo-me reduzido à este pequenino corpo, a este restinho de alento, ainda Vm. vem com os seus malditos conselhos de moderação, e de magnanimidade fora de tempo, que deram azos a esses vis inimigos caramurus. ${ }^{104}$

Na verdade, O Sete d'Abril acusava a Aurora e os moderados que seguiam a sua linha, do "empecimento da marcha da revolução," 105 pois deixaram de fazer "coisas que reclamavam a salvação da nossa pátria, e segurança de nossos direitos e liberdades." 106 Acusavam-Ihes de armarem aqueles que atentaram contra a "dignidade nacional"107 em março de 1831, ao invés de puni-los. Apontava que não cumpriram satisfatoriamente as "promessas de serem tomadas contas aos ex-Ministros d'Estado, da passada administração." ${ }^{108}$ Enfim, criticava os moderados por deixarem o Senado opor-se obstinadamente a "tudo quanto interessa à Nação," 109 retardando 
110

Ibidem.

111

Ibidem.

112

Idem, n.115-Extraordinário, 30/01/1834, p.1-3.

113

Idem, n.117, 04/02/1834, p.1-2.

114

Folhas ministeriais do Primeiro Reinado.

115

O Sete d'Abril, n.117, 04/02/1834, p.1-2.

116

Idem, n.187, 11/10/1834, p.1-2.

117

Idem, n.215, 24/01/1835, p.4.

118

Biblioteca Nacional. Cartas de Evaristo da Veiga ao irmão João Pedro da Veiga. 13/12/1836. I-02. Apud. ANDRADE, Marcos Ferreira de. Elites regionais e a formação do Estado Imperial brasileiro...0p. Cit., p.141.

119

O Sete d'Abril, n.265, 28/07/1835, p.3. o Código do Processo e mutilando as reformas constitucionais. Contudo, o redator ressaltava que não fora sua a ideia do estabelecimento de uma Assembleia Constituinte, por ocasião da tentativa de golpe de Estado em 1832, mas dos "brasileiros mais exaltados no dia da nossa regeneração." 110 Interessante colocar que o redator assumia antes, sua parcela de culpa mediante a situação vivida no Brasil, "por termos sempre pertencido ao partido moderado, com algumas restrições." 111

Um dos principais pontos de conflito entre $O$ Sete d'Abril e a Aurora de Evaristo, diz respeito ao Ministério, no qual Aureliano de Souza e Oliveira Coutinho tinha maior destaque. $O$ Sete d'Abril censurava a defesa que a Aurora fazia ao Ministério e a sua afirmação de que os opositores estavam dando forças aos caramurus: "Quem dá mais gosto aos caramurus; quem censura para que se acautelem, ou quem louva e ainda se cala, para que se precipitem." 1120 Sete assimilava a atuação desse Ministério com aqueles existentes no tempo de D. Pedro I, assim como a das folhas que o defendiam, com os jornais ministeriais de outrora. Assim, apontava que apesar da perseguição que vinha sofrendo por parte da justiça, o Sete haveria de continuar censurando o Ministério, apontando "seus erros, sua incúria, suas faltas e seus crimes, porque são responsáveis, porque são matéria sujeita à crítica." ${ }^{113} \mathrm{E}$ advertia que os destinos dos ministros e escritores da situação seriam parecidos com os de seus pares do Primeiro Reinado:

\footnotetext{
Uma verdade asseguramos nós aos nossos Ministros, e é que a sua posição vai se assemelhando muito à dos ministros do ex-Imperador; e a dos jornais seus defensores, à do Diário Fluminense e Analista ${ }^{114}$. Reduzidos a um pequeno círculo, e este pela maior parte composto de empregados públicos, eles equivocam a opinião destes com a opinião Nacional, e marcham ao precipício. Em tal apuro os seus escritores, hão de tornar-se nulos ou enfurecer-se; e de qualquer modo, o não poderão salvar. Isto é infalivel, embora a Aurora, e a sua cauda o Correio Official, os julgue em leito de rosas. ${ }^{115}$
}

O Sete d'Abril não aceitava o título de "moderado" para Evaristo e seus aliados no governo. Ao invés disso preferia tratá-los como "marrecos". Desta forma, levantava dúvidas sobre a orientação política dos mesmos: "Todavia, não podemos deixar de examinar se os moderados do Brasil têm direito a este título, se eles são inimigos dos erros e exagerações das opiniões extremas em Política." ${ }^{116}$ Em 1835 recusava a afirmação da Aurora de que ainda não sabia o que era "marreco"; "Forte inocente!! Para que explica então que "marreco" é todo aquele que dobra o joelho diante de certo idolo, e jura nas palavras do Mestre reconhecendo a sua infalibilidade? Que rechonchudo marreco!!" 117 . Assim, os marrecos seriam todos aqueles que se julgavam reciprocamente infaliveis e não ouviam as criticas, ou seja, era o ministério e seus apologistas. E "rechonchudo marreco" poderia ser uma alusão clara ao tipo físico de Evaristo, que, alguns anos mais tarde, em visita aos seus irmãos no Sul de Minas, fez pilhérias de si próprio quando se encontrou com seu sobrinho-afilhado, filho de seu irmão Lourenço, que Ihe perguntou: "Que homem é este tão barrigudo?" 118

Com a queda do ministério Aureliano, o Sete continuou atacando Evaristo, afirmando que seu desejo era sempre governar "por trás das cortinas" 119 e que, para isso, sempre buscava ajustar-se às circunstâncias. Transcreveremos, pois, trechos da correspondência de "O Padrinho de Evaristo", a qual também representa o parlamentar como um anarquista, rejeitando-Ihe o título de republicano, embora citasse em sua Aurora, 
Proposta defendida pelo Sete, na ocasião da eleição do regente uno. Talvez o redator do Sete estivesse com medo da eleição de Feijó, o qual tinha maior afinidade com Evaristo.

123

O Sete d'Abril, n.265, 28/07/1835, p.3-4.

124

Ibidem.

125

Ibidem.

126

Ibidem.

127

Ibidem.

128

Idem, n.269, 11/08/1835, p.3

129

Idem, n.262, 14/07/1835, p.4

130

Maiores detalhes sobre a primeira e única viagem de Evaristo ao Sul de Minas Gerais ficaram registradas por sua própria pena, desde a saída da Corte, em novembro de 1836, durante os meses que ficou em companhia dos irmãos na vila de Campanha, até o seu retorno à cidade do Rio de Janeiro, no início de maio de 1837. Tratase de 19 cartas que Evaristo da Veiga escreveu para o seu irmão João Pedro da Veiga, que residia no Rio de Janeiro, dando detalhes de sua viagem, estadia na vila de Campanha, notícias dos irmãos que ali residiam e dos parentes que não conhecia alguns comentários sobre o contexto político e informações sobre o seu retorno à Corte. Essas correspondências foram analisadas pioneiramente por Otávio Tarquínio e, mais recentemente, por Marcos Andrade. Ver. SOUZA, Otávio Tarquinio. Op. Cit.; ANDRADE, Marcos Ferreira de. Familia e política nas Regências..., Op. Cit. pensadores desse sistema de governo, como Achilles Murate Jefferson:120 "Que hábitos republicanos contraiu o nosso Doutor de La Veiga no balcão do Sr. seu pai, vendendo cartilhas, pautas e tabuadas, lendo a gazeta ou na meditação devota do ripanso para obter um emprego no Paço?" ${ }^{121}$ Dessa forma, o correspondente pareceu desprezar os conhecimentos que Evaristo pudesse ter adquirido dos princípios republicanos ou de quaisquer outros, de forma autodidata. Ao invés disso, apontou que ele estava era espalhando a anarquia ao se colocar contra a devolução da Regência à princesa D. Januária, ${ }^{122}$ alegando que isso iria "apressar a queda dessa Monarquia, que de todos os lados está cercada de repúblicas." 123 E questionava: "Por ventura a Monarquia no Brasil só se sustentará enquanto houverem Regentes, da ordem destes que o Sr. de La Veiga proponha?"124

Nessa mesma missiva foi rejeitada outra representação de Evaristo, como o Robespierre da Sociedade Defensora, na qual exercia o cargo "perpétuo" ${ }^{125}$ de secretário. Apontou-se a distância entre Veiga e o revolucionário francês, sobretudo no que dizia respeito à firmeza política e coerência. Ao contrário de Robespierre, Evaristo seria o "homem das cessões," 126 "das condescendências e das contemplações." ${ }^{127}$ Ademais, a julgar pelo modo como o Sete referiu-se à Defensora em várias outras passagens, podemos concluir que seu redator, embora se dissesse moderado, não participava da associação, ou ao menos, não mais.

0 redator de o Sete buscava ainda depreciar a figura de Evaristo da Veiga junto a seus eleitores mineiros, como no artigo intitulado "Mestre Evaristo: Considerado como escriba e Deputado".

Heroica província de Minas Gerais! Bem quisera o Sete d'Abril poupar-vos ao dissabor de vos retratar esse homem que tem merecido por duas vezes vossos sufrágios, que tantos males tem feito à Pátria, que se tem proclamado o árbitro soberano de todas as reputações (...). ${ }^{128}$

Na ocasião das preparações para a viagem de Evaristo a Minas, o redator assim se refere:

Parabéns, ó mineiros! (...) 0 Sr. Evaristo vai honrá-los com uma visita... concertam-se as estradas, preparam-se as liteiras, engordam-se os burricos, lavam-se e pintam-se as casas em que o nosso divino parlamentar tem designado passar as noites, um novo pálio se há comprado para a sua recepção na primeira Vila onde será recebido (...). Quando porém um personagem como o Sr. Evaristo abandona, bem que interinamente, a direção dos negócios públicos, aparta-se se de sua família para embrenhar-se nos bosques, grandes e importantes devem ser os motivos de tão pesado sacrifício. ${ }^{129}$

A citação acima deixa implícita a ideia, de que Evaristo estava perdendo seu apoio político em Minas, uma vez que era a primeira vez que se preocupava em fazer uma visita à província. Além disso, ao referir-se à necessidade do conserto de estradas para que a viagem ocorresse, deixava subtendido que a província estava abandonada à sua própria sorte. Talvez sua intenção fosse lembrar aos mineiros que Evaristo não cuidava bem da sua região. Além disso, não podemos deixar de ressaltar que a necessidade apontada de engordarem-se os burricos, trata-se de uma provocação, uma vez que Veiga era obeso. ${ }^{130}$

Enfim, o Sete criticaria Evaristo até a sua morte, em 1837. Quando Veiga anunciou que pretendia encerrar as suas atividades na Aurora, o redator referir-se-ia ao fato associando-o ao enriquecimento de Evaristo. 
131

O Sete d'Abril, n.294, 14/11/1835, p.4

132

Idem, n.288, 24/10/1835, p.4.

133

Idem.
134

Arquivo Nacional. Inventário Post-Mortem Evaristo Ferreira da Veiga. 1837. Maço 442, n.8532, p.7.
"Mestre Evaristo, tendo abandonado o Balcão e o ofício de mercador de livros, quer também fazer cessar a publicação da Aurora Fluminense, bem que the renda (segundo ele assevera) muitos mil cruzados: mas para que precisa de pingos de cera um dos mais opulentos capitalistas do Brasil?" ${ }^{131}$ Um pouco antes, respondera a Evaristo que não desprezava sua profissão de livreiro, mas estranhava que no "curto espaço de 6 anos, abandonásseis vossa indústria útil de livreiro, como que já não quadre à vossa alta personalidade, que comprásseis grande casa de sobrado em lugar de comércio de grosso trato, e que em tão pouco tempo vos habilitásseis a viver sem trabalho." ${ }^{132} \mathrm{E}$ mais adiante insinua, sem se comprometer: "Também não disse o Sete d'Abril que vós fazíeis transações com o Tesouro...o Sete d'Abril ignora se vós tendes feito algumas transações lucrativas, bem que por aí se diz que alguns dos empregados mais corrompidos são criaturas vossas." ${ }^{133}$ Assim, deixa explícita a suspeita de que Evaristo fosse corrupto e dai adveio a sua riqueza repentina.

Ao que tudo indica, a acusação do Sete parece infundada e trata-se de uma estratégia, bastante comum na imprensa periódica da época, de utilizar o prelo não só para o debate das ideias políticas, mas também para formular argumentos depreciativos e acusações entre os redatores dos principais jornais e lideranças políticas de destaque. Se considerarmos o inventário dos bens de Evaristo, grande parte de sua riqueza estava relacionada à atividade de livreiro, que desenvolveu durante boa parte de sua breve e intensa vida, e ao sobrado adquirido antes de se destacar na cena pública. Em 1837, ano de sua morte, a sua residência e loja foram assim descritas:

\begin{abstract}
Uma morada de casa de dois sobrados, sita na rua dos Pescadores número vinte e cinco, a qual tem de vão vinte e cinco palmos (...). A sua formação na frente é de pedra e cal, com três portais de cantaria na Loja, e três janelas com varandas de cantaria, no primeiro andar e três janelas de peitoril de madeira no segundo andar, com seus caixilhos de vidraças e grades de ferro; as paredes dos lados são de pedra e calmeeiras, as divisões de estuque; repartido o primeiro andar, sala, alcova, sala de jantar, alcova, cozinha e despensa; e da mesma forma o segundo andar, tendo de mais uma escada interior que desce para o primeiro andar; tem mais um sótão repartido em sala e dois corredores com janelas para cima do telhado e para a frente da Aria (sic): a loja toda aberta; tudo forrado, menos as cozinhas, o corredor da rua e a dita loja assoalhada avaliada em doze contos e oitocentos mil réis. ${ }^{134}$
\end{abstract}

\section{Considerações Finais}

Evaristo Ferreira da Veiga era de fato o membro mais combatido do grupo moderado, o que demonstra a posição de destaque que ali detinha. Atacado por exaltados, caramurus e até mesmo por outros moderados, Evaristo era representado como um traidor da causa do 7 de Abril, um tirano que perseguia todos os não adeptos da moderação e, contraditoriamente, um fraco, que não tomava as medidas necessárias para destruir aqueles que representavam perigo para a pátria. Sua profissão de livreiro era sempre ressaltada, ora para mostrar que não era nobre o suficiente para dirigir a Nação, ora para lembrar que não Ihe permitiria acumular fortuna, e com isso, provar a sua corrupção. Seus conhecimentos, adquiridos em grande parte por meio das obras da livraria de seu pai, suas capacidades e caráter eram questionados. Afinal, o que um vendedor de livros poderia saber dos princípios republicanos? Aliás, a Evaristo da Veiga não se atribuía princípio algum, posto que seu objetivo era simplesmente governar por "detrás das cortinas." Nesse sentido, sua maior habilidade era ajustar-se às circunstâncias, ser condolente com quem estivesse no poder, já que não tinha firmeza política. 
135

A noção de "representações" utilizada neste trabalho aproxima-se daquela defendida por Le Goff, o qual assevera que "o campo das representações engloba todas e quaisquer traduções mentais de uma realidade exterior percebida", e está ligado ao processo de abstração. Ver. LE GOFF, Jacques. 0 imaginário Medieval. Lisboa: Estampa, 1994. p.11. Também Roger Chartier se exprimirará de tal forma, acrescentando que as representações inseremse "em um campo de concorrências e de competições cujos desafios se enunciam em termos de poder e de dominação", produzindo verdadeiras "lutas de representações." Desta forma, o modelo apresentado por Chartier para uma análise da História Cultural também é adequado para a História Política, posto que por meio das lutas de representações, podemos acompanhar as disputas travadas em torno do poder. Ver. CHARTIER, Roger. A história cultural: entre práticas e representações. Tradução de Maria Manuela Galhardo. Rio de Janeiro: Bertrand Brasil, 1990. p.17. Idem. À beira da falésia: a história entre incertezas e inquietude. Porto Alegre: Ed. Universidade/UFRGS, 2002. p.73.

136

MOTTA, Rodrigo Patto Sá (org.). Culturas políticas na história: novos estudos. Belo Horizonte: Argvmentvm, 2009. p.23.

137

ANDRADE, Marcos Ferreira de. Família e política nas Regências..., Op. Cit., p.261-265.

138

SOUZA, Otávio Tarquinio de. Op. Cit.
Para seus opositores, a moderação de Evaristo era fingida. Ele era igualado aos déspotas que combatera no Primeiro Reinado. Assim como eles, apoiava as leis de exceção, com suas prisões sem culpa formada e desrespeitos às garantias legais dos cidadãos. Por outro lado, o título de "moderado" poderia ser uma alusão ao Poder Moderador, posto que julgasse a si e seus aliados, invioláveis, ou quem sabe, sagrados. Melhor mesmo era tratá-los como "marrecos", ou seja, aqueles que confiavam na infalibilidade própria e dos seus. Nesse sentido, todas as críticas eram injustas, infundadas e seu objetivo era fortalecer o inimigo.

As representações que os adversários políticos faziam de Evaristo tinham o claro interesse de fazê-lo perder o conceito público ${ }^{135}$. Mas isso não nos autoriza a considerá-las um amontoado de mentiras ou calúnias. As representações e as práticas não devem ser opostas, como se houvesse entre elas uma clara linha de determinação. As ações influenciam as representações, que nelas se inspiram e buscam forma, e também garantem sua reprodução através de práticas rituais. Por outro lado, as representações ou os diferentes modos como os grupos figuram o mundo são determinantes para suas escolhas e ações, pois os homens agem a partir de apreensões da realidade. ${ }^{136} E$ evidente que as representações tinham um fundo de verdade, de outro modo, não alcançariam o interesse do público leitor. Ademais, elas contribuíram para o descrédito gradual dos moderados, que afinal acabaram derrotados em 1837, quando se iniciou a fase conhecida como Regresso. E Evaristo da Veiga viria a falecer justamente no dia 12 de maio daquele fatídico ano, aos 37 anos, depois de deixar a vila de Campanha, no sul de Minas Gerais. Tratava-se de um momento de redefinição política que já vinha desenhando-se a pelo menos dois anos antes, quando encerrou a publicação da Aurora, em dezembro de $1835 .{ }^{137}$ Como bem caracterizou Otávio Tarquinio de Souza, o publicista da Regência teve uma "vida breve" e uma "morte oportuna." 138 